\title{
Hvorfor, hvorfra (og hvornår) kom religion ${ }^{1}$
}

\author{
ARMIN W. GEERTZ
}

ENGELSK SUMMARY: "Why, Wherefrom (and When) Did Religion Appear?" This article presents my reflections on the evolution of religion from the perspective of the cognitive science of religion and the neurobiology of religion. Two important features of the brain were crucial to our evolution, i.e. the expansion of the emotional and subcortical areas on the one hand and the cortex on the other. The former was essential to the development of viable social systems and the latter to the development of stone tool technologies and material culture. Furthermore, the growth of the brain was apparently due to the growing complexity of human social structures that culture brought with it. A key feature of the brain is that it is incomplete in human infants and is first fully matured after two decades of social and cultural life: the unfinished animal that becomes completed through a particular culture. Looking closer at the neuropsychological evidence of our brains and behavior, I have identified four key human features, namely, a finely honed social cognition, a drive to communicate and cooperate, a self-deceptive brain and a superstitious brain prone to unusual mental and/or emotional experiences. These traits, I argue, are prerequisites for religious behavior. In looking through the archaeological records, there is good reason to look beyond our species into the deep hominin past. A likely candidate that seems to have evinced proto-religious behavior is Homo heidelbergensis (between 600,000 and 400,000 years ago).

DANSK RESUMÉ: I denne artikel præsenterer jeg med udgangspunkt i den kognitive og den neurobiologiske religionsvidenskab mine refleksioner over religionens evolution. To aspekter af hjernen er afgørende for vores evolution. Den ene er udvidelsen af de emotionelle og indre dele af hjernen og den anden er udvidelsen af hjernebarken. Førstnæonte

1 Tak til institutsekretær Bente Langballe Kejser og prof. Anders Klostergaard Petersen begge ved Institut for Kultur og Samfund, Afdeling for Religionsvidenskab, Aarhus Universitet for sproglig assistance. En væsentlig del af arbejdet, der er præsenteret i denne artikel, skyldes en UNIK-bevilling fra det daværende Ministeriet for Videnskab, Teknologi og Innovation, som har finansieret en tværvidenskabelig international forsknings-koalition ved navn MINDLab ved Aarhus Universitet. Tak også til kollegerne ved Religion, Cognition and Culture (RCC) forskningsenheden på Institut for Kultur og Samfund. Tak også til Aarhus Institute of Advanced Studies og Aarhus Universitetsforskningsfond for et Jens Chr. Skou Senior Fellowship. 
var en nødvendig forudsætning for udviklingen af levedygtige social systemer og sidstnæonte for udviklingen af stenredskaber og anden materiel kultur. Hertil kommer at hjernens udvikling hang kausalt sammen med den voksende social kompleksitet og den kulturelle udvikling, som denne kompleksitet førte med sig. Hjernen har den særlige egenskab, at den ikke er fuldt udviklet ved fødslen og først er "moden" efter to årtiers sociale og kulturelle liv, hvor også hjerneskallen forst er vokset endelig sammen (for kvinder 18 år for mænd 21 år). Således bliver det ufxrdige dyr færdiggjort inden for en specifik kultur. Når man ser på de seneste landvindinger inden for neuropsykologien, er der fire kendetegn, som jeg mener, er konstituerende for mennesket. Disse er: en finudviklet social kognition, en kommunikations- og samarbejdsdrift, en bedragerisk hjerne samt en overtroisk hjerne med tendens til ualmindelige mentale og/eller emotionelle oplevelser. Disse egenskaber er en nødvendig forudsætning for religiøst adfard. Når man ser på de arkæologiske vidnesbyrd i jagten på det religiøse menneske, skal man gå betydeligt længere tilbage end Homo sapiens, ja, man skal langt tilbage $i$ homininlinjen. De første proto-religiøse træk synes at komme til syne med Homo heidelbergensis (mellem 600.000 og 400.000 år siden).

KEYWORDS: religion; evolution; cognitive science of religion; definition of religion; neurobiology of religion; method and theory in the study of religion.

\section{Om evolution og den kognitive religionsvidenskab}

Langt de fleste pionerer inden for den kognitive religionsvidenskab har anskuet den menneskelige kognition i lyset af evolutionsteori (Geertz 2004a; 2005; Geertz \& Markússon 2010). De kognitive antropologer Pascal Boyer og Scott Atran har imidlertid begge argumenteret for, at religion ikke har haft nogen selektionsværdi i menneskeartens evolution. De forslag, som er blevet fremført i religionsvidenskaben og antropologien om, hvad religion er, og hvorfor vi har den, har ingen forklaringsværdi, siger Boyer og Atran, men består snarere af en række fænomener, der skal forklares yderligere. Det drejer sig om:

1. religion giver årsagsforklaringer

2. religion giver mennesket trøst

3. religion sikrer samfundsorden

4. religion er en kognitiv illusion

5. religion hjælper mennesket med at håndtere døden

6. religion sikrer moralsk orden

7. religion erstatter menneskets tabte barndomstryghed

8. religion erstatter eller sublimerer seksualdriften

9. religion provokerer intellektuel overraskelse og ærefrygt (Boyer 2001, 5; Atran 2002, 12-13) 
De mener begge, at disse forklaringer for så vidt ikke er forkerte. De kan tværtimod være informative og indsigtsfulde. Men ingen af dem kan isoleret fungere som kausal forklaring på religionens tilblivelse. Boyer og Atran søger så i den menneskelige kognition for at finde de basale mekanismer, som mennesker trækker på, når de handler eller tænker religiøst. De gør det i den overbevisning, at man ikke kan finde forklaringer i den kulturelle mangfoldighed. Man kan kun finde kausale forklaringer i den menneskelige kognition, som blev til under artens evolution.

Som flere har påpeget, hviler denne argumentation på en meget snæver forståelse af den menneskelige kognition (Jensen 2003; 2009; Geertz 2010a). Den opfattelse, der er tale om, går ud fra, at den enkeltes kognition - og primært mentale repræsentationer - er uafhængig af sociale, kulturelle, ja sågar kropslige eller emotionelle faktorer. Kulturen er et epifænomen til og en snylter på vor kognition. Den holdning har jeg taget afstand fra og har gjort mig til talsmand for den grundlæggende præmis i vort arbejde på Religion, Cognition and Culture (RCC) forskningsenheden i Aarhus, at den menneskelige kognition både er dybt kropsligt betinget og forankret (emotionelt, kemisk, neurologisk mv.) og dybt kulturelt forankret og betinget. Desuden karakteriseres den menneskelige kognition som kontekstuel, udspredt i sociale sammenhænge og både forankret i og udtrykt igennem materielle genstande og sammenhænge. Merlin Donald $(1991 ; 2001)$ er en af de mest kendte fortalere for denne forståelse; men der er en række fremtrædende filosoffer, biologer, psykologer, arkæologer, neurologer og andre fagfolk, som har samme opfattelse. ${ }^{2}$

Vi er kulturmagere og kulturbrugere, og vi søger tilflugt i vores sociale grupper. Vi kan ikke bruge vores store hjerner uden kulturens gitterværk eller stillads (scaffold). Vi har som art gennem kulturen ganske enkelt og bogstaveligt talt overtaget og domesticeret vores egen biologiske udvikling (Deacon 2003, 93-95). Kulturen har "befriet os fra vores dyriske solipsisme, dvs. at vi er i stand til at forestille os interne og eksterne modeller af selvet-i-verden ved brug af social tilknytning (bonding) og kulturelle konventioner" (Geertz 2008a, 22). Vi er fundamentalt set en del af kollektive videns-, følelses- og hukommelsesnetværk, som Merlin Donald formulerer det, og disse netværk er kulturens kerne.

Derfor er det lidt mærkeligt at forestille sig - som den tidlige kognitive religionsvidenskab har gjort - den menneskelige kognition uden kultur. Det kan være, at man af heuristiske grunde kan adskille kulturelle begrænsninger ('cultural constraints') fra kognitive ('cognitive constraints'); men denne adskillelse er umulig at udføre i eksperimentelle sammenhænge, selvom det sagtens kan gøres i tankeeksperimenter. Som jeg lidt polemisk har skrevet: "Imagining humans without culture may be a good exercise in off-line cognition, but it is also clearly off-the-wall. We need to take culture into account" (Geertz 2008b, 45).

Derudover kan man spørge, hvad har vi lært af den kognitive religionsvidenskabs pionerer? Indtil videre har fremskridtet været behersket. Og ingen af de fremførte hypoteser er tilstrækkelige som kausale forklaringer på religionens oprindelse, om

2 Som fx Clark 1997; Rowlands 2003; Deacon 1997; Tomasello 1999; Richerson \& Boyd 2005; Plotkin 2002; Sterelny 2003; 2012; Renfrew et al. 2008; Frith \& Frith 2010. 
det så drejer sig om Pascal Boyers modintuitive ideer (2001), Stewart Guthries animisme- og antropomorfisme-teori (1993), Justin Barretts HADD-mekanisme ("hyperactive agency detection device"; 2004) eller Harvey Whitehouses modalitetshypotese (2000). Det samme gælder biologernes mem-teori (Dawkins 1976; 2006; Dennett 2006) og antropologen Dan Sperbers epidemiologiske teori (1996). ${ }^{3}$ Disse hypoteser og teorier kan godt have noget på sig; men de kan næppe antages at være kausale årsager til religionens oprindelse. Og dette skyldes primært, at de efter min mening alle hviler på en fejlagtig kognitionsforståelse.

For at forstå menneskets evolutionære udvikling bliver man nødt til at ændre sin opfattelse af forholdet mellem kognition og kultur. Man må, mener jeg, give afkald på såvel computermodellen af den menneskelige kognition som de solipsistiske, epifænomenalistiske og mentalistiske modeller. Vi skal desuden se meget længere tilbage end Homo sapiens' oprindelse for at finde religionens fremkomst - ja, vi skal helt tilbage til vores primatlinje for at finde os selv (Geertz 2008b, 47). Scott Atrans berømte udsagn om "stone age minds for a space age world" (2002) peger på evolutionspsykologernes opfattelse, at vores kognition blev udviklet i den pleistocæne tid (det tidsrum hvori Homo-linjen opstod) i forhold til savannens betingelser (den såkaldte "environment of evolutionary adaptedness" eller EEA; Crawford \& Krebs 2008 , 15). Men vi skal også noget længere tilbage i tiden; for hvis der er noget, som man med sikkerhed kan sige om mennesket, så er det, at vi er nogle ekstremt intelligente og hidsige aber.

\section{Den følelsesladede, ritualfikserede abe}

Menneskeaberne opstod i Centralafrika for 25 millioner år siden. De havde deres storhedstid imellem 15 og 8 millioner år siden med over 100 forskellige arter. Men i forbindelse med et drastisk temperaturfald og Riftzonens opståen (mellem 10 til 8 millioner år siden) ændredes det østlige Afrika til skov og senere til savanne. Menneskeaberne uddøde i Europa, og kun orangutangen og gibbonen overlevede i Sydøstasien. I Afrika overlevede stamfaderen til gorillaerne, chimpanserne, dværgchimpanserne og mennesket, som var indvandret fra Europa til Afrika for ca. 9 millioner år siden (Jensen 2004, 39-41). Som genforskeren Peter K. A. Jensen noterer:

[D]et var i Østafrika omkring dette tidspunkt [ca. 6 millioner år siden], at en ny type af primat opstod - et dyr, der ikke var så forskelligt fra dets forfædre blandt menneskeaberne - bortset fra i én, meget afgørende henseende: Det nye dyr stod oprejst på to ben. ... [D]en nye primats efterkommere ville udvikle en stor hjerne (selv om det først skete flere millioner år efter, at forfaderen rejste sig op fra jorden). (Jensen 2004, 42)

Denne nye primat var inddelt i tre slægter: Ardipithecus, Australopithecus og Homo. De to første, som med en fællesbetegnelse kaldes 'australopithecinerne', var opretgående menneskeaber, som både anatomisk og mentalt var meget lige menneskeaberne (Jensen 2004, 47). Homo-linjen derimod, som opstod i forbindelse med den tiltagende

3 Se Jesper Sørensens kritik af denne teori (Sørensen 2004; 2007a). 
tørke for ca. 2,5 millioner år siden, var anderledes i den forstand, at de forlod skoven og bevægede sig ud i den tørre og åbne savanne, hvor menneskeaberne ikke kunne leve.

\begin{tabular}{|l|l|l|}
\hline Superfamilie & Hominoidea & $\begin{array}{l}\text { Hominoider - alle menne- } \\
\text { skeaber og mennesker }\end{array}$ \\
\hline Familie & Hylobatidae & Gibboner og siamanger \\
\hline Familie & Pongidae & Orangutanger \\
\hline Familie & Hominidae & $\begin{array}{l}\text { Hominider (omfatter } \\
\text { både gorillaer, chimpan- } \\
\text { ser, bonoboer og homini- } \\
\text { ner) }\end{array}$ \\
\hline Hominidae-subfamilie & Gorillinae & Gorillaer \\
\hline Hominidae-subfamilie & Paninae & Chimpanser og bonoboer \\
\hline Hominidae-subfamilie & Hominiae & $\begin{array}{l}\text { Homininerne - menne- } \\
\text { sket herunder også au- } \\
\text { stralopithecinerne (genus } \\
\text { Homo, Australopithecus, } \\
\text { Paranthropus og Ardipi- } \\
\text { thecus) }\end{array}$ \\
\hline
\end{tabular}

Skema 1. Primatarternes familietilhørsforhold - genetisk bestemt. Klassifikationen ændres hele tiden. Der er fx tvivl om, hvorvidt Paninae er en del af Hominiae-subfamilien. Dette skema er baseret på Nickels 2006; se Goodman et al. 1990 angående DNA-analyserne og "Ape" i Wikiwand W (07.09.2017) for klassifikationsændringernes historie.

Klassifikationen af arternes familietilhørsforhold har ændret sig en del. Men siden indførelsen af genetiske fossilundersøgelser er man blevet enige om, at superfamilien Hominoidae rummer alle menneskeaber og mennesker. Denne superfamilie har tre familier: Hylobatidae (gibboner og siamanger), Pongidae (orangutanger) og Hominidae (hominider) - se skema 1. Sidstnævnte familie rummer tre subfamilier: Gorillinae (gorillaer), Paninae (chimpanser og bonober) og Hominiae (homininerne, dvs. australopithecinerne og Homo-linjen). Mennesket, chimpanserne og bonoberne er de nærmeste beslægtede i hominidlinjen og det giver derfor god mening, at man sammenligner deres adfærd og psykologi med vores. Med det store DNA-fællesskab, som vi har med pan-linjen eller paninerne (ca. 98-99\%), mener forskerne, at vores fælles stamforældre sandsynligvis haft en mosaik af de egenskaber, som man finder hos paninerne og homininerne (Sapolsky 2017, 365).

Homininernes evolution udgør et opsigtsvækkende paradoks: Vi burde ikke kunne have overlevet savannens udfordringer. Denne kendsgerning er tankevækkende på to måder: Dels var arten nøgen og forsvarsløs, dels kom arten fra en linje med et meget løst socialsystem. I kraft af vores fælles stamforældre delte vi sidstnævnte med chimpanserne, orangutangerne og gorillaerne. 
Disse to problemer - forsvar og social system - blev løst ved udviklingen af stenredskaber og af et i dyrerigt relativt unikt social system. Disse to opfindelser gjorde det muligt for homininerne ikke alene at forlade skoven, men også at brede sig ud over hele kloden. Begge opfindelser skyldes hjernens udvidelse i to områder, nemlig følelsesområdet som den første ekspansion og hjernebarken som den anden. De to udvidelser udgør kernen i den hominine evolution.

I en bog med titlen The Emergence and Evolution of Religion: By Means of Natural Selection har sociologen Jonathan H. Turner, antropologen Alexandra Maryanski samt Anders Klostergaard Petersen og jeg selv fremhævet den første udvidelse af hjernen som hovedårsagen til udviklingen af et nyt socialt system, som gjorde det muligt for homininerne at overleve savannens farer (Turner et al. 2017). Bogens grundtanke bygger på Turners og Maryanskis arbejde inden for feltet "emotionssociologien" (Turner 2000; Turner \& Maryanski 2008; Turner \& Stets 2005).

Argumentet er, at det på grund af en forøget social solidaritet og evnen til at organisere sig i mere permanente grupper er lykkedes homininerne at forlade skoven. Disse evner er til dels åbenlyse i alle menneskeaber; men selektionspresset på det, Maryanski kalder "community complex" (dvs. samfundskompleks; Maryanski 2013; 2018), førte til en nuanceret vifte af sociale systemer. Denne egenskab bygger på den durkheimske evne til at forestille sig et samfund eller fællesskab, som ligger ud over de daglige nærforhold, hvor man er i stand til at forestille sig selv som objekt, dvs. et selv med en identitet. Disse evner var en nødvendig forudsætning for religionens opståen. Homininerne synes at tillægge samfundet om ikke noget helligt, så i al fald noget emotionelt specielt. Sidstnævnte opretholdes gennem ritualer, som stimulerer følelserne omkring fællesskabet og ved at rette dem mod et fælles objekt giver dem en mere permanent karakter. De seneste undersøgelser af chimpansernes samlinger peger i retning af, at de også (og dermed også vores fælles stamfader) har det i rudimentært form (Turner et al. 2017, 5-6). Som man kan ane, spiller Durkheim en stor rolle i hypotesen. Men kernen i argumentet er, at religion opstod som led i en meget, meget langvarig akkumulation af kognitive og sociale egenskaber:

This bundle of inherited traits, coupled with a sense of community, with the capacity to see self in relation to community, with reliance on emotionally charged rituals, with proto-conceptions of the sacred, with representations of the sacred with what might be totems, made the emergence of religion almost inevitable in human societies. This was especially so as the hominin neo-cortex began to grow with the appearance of early Homo species. (Turner et al. 2017, 6)

I bogen dokumenterer vi, hvorledes religion er opstået i forlængelse af de kognitive, emotionelle og adfærdsmæssige egenskaber, som findes den dag i dag hos menneskeaberne. Det, vi især søger at forklare, er, hvordan vi som art er blevet så følelsesladet, som vi er.

Alexandra Maryanski har udført en netværksanalyse i kombination med en kladistisk analyse over menneskeabernes sociale systemer i forhold til småabernes for at finde frem til hominoide-stamforældrenes socialsystem (Maryanski 1992; 1993; 1995). Resultaterne viser, at stamfaderens sociale tilhørsforhold ligesom hos orangutangerne var meget løse, når man ser bort fra moder-børn-forholdet, som dog opløses 
ved puberteten, hvor både hanner og hunner forlader gruppen. En senere udvikling, som kan ses i gorilla-linjen, er hannens bidrag til ungernes opvækst og en mere stabil gruppe. Med chimpanserne forbliver hannerne i gruppen, hvorimod hunnerne forlader den. Disse grupperinger er imidlertid ikke permanente. Dette forhold står i modsætning til de fleste småaber, som har mere permanente hierarkiske grupperinger. Der er ikke plads her til en mere detaljeret redegørelse. Det, der udgør hovedspørgsmålet, er: Hvordan har en art med en meget løs samfunds- eller gruppestruktur overlevet savannen? Det er netop her, emotionerne kommer ind i billedet.

Maryanski har også udført en kladistisk analyse af emotionsområderne i hjernen hos henholdsvis chimpanserne og mennesker i forhold til Tenrecinae (en meget lille abe). Analysen viser, at vores emotionsområder er dobbelt så store som chimpansernes, og at denne udvikling er foregået gennem flere millioner år længe før udvidelsen af hjernebarken (Turner et al. 2017, 82ff.). Samtidig kan man se en udvikling af hjernens Broca-område, hvilket giver større kontrol over følelsesytringer. Chimpanser larmer, når de er ophidset; men det går ikke på savannen, for det ville kunne tiltrække farlige rovdyr.

Hvad skulle vi med alle disse følelser? Hypotesen er, at homininerne fik en bredere vifte af følelser, der gjorde det muligt at udvikle personlige forhold gennem fx kærlighed og en betydelig større tilknytning til gruppen, der blev styrket gennem ophidsende ritualer. Igen er der ikke plads til en detaljeret redegørelse, som er ret teknisk. ${ }^{4}$ Opsummerende kan man konstatere, at vores art har måttet løse problemet med en løs sammenhængende socialitet. Det var en elementær forudsætning for at overleve bevægelsen ud på savannen. Det lykkedes gennem udviklingen af nogle subkortikale hjerneområder. Det faktum, at Homo sapiens sapiens' sociale udvikling tilsyneladende består af det ene elendige samfundssystem efter det andet, er måske udtryk for, at vi, som også Durkheim pointerede, som art rummer en spænding mellem individualistiske og kollektivistiske egenskaber. Hvis et system ikke giver både sikkerhed og mulighed for menneskelige udfoldelse, eller hvis det bliver truet af andre mere ubehagelige samfund, bliver det løst gennem ekstreme følelser som ved fx drab, revolution og krig.

\section{Kultur og stenredskaber}

Det andet vigtige led i vores evolution og religionens oprindelse er den opsigtsvækkende udvidelse af hjernebarken. Størrelsesforholdene i skema 2 taler for sig selv: fra Australopithecus med ca. $450 \mathrm{~cm}^{3}$ hjerne (nogenlunde svarende til en chimpansehjerne) til Homo neanderthalensis med ca. $1450 \mathrm{~cm}^{3}$. Homo sapiens har en mindre hjerne end neanderthalerne med ca. $1350 \mathrm{~cm}^{3}$ - nogle har ligefrem talt om en reduktion af hjernen

4 Neurologiske undersøgelser af indersiderne på hovedskal hos australopicenerne og aber udgør en vigtig understøttelse af Maryanskis analyse. Se fx Vilensky, Van Hoesen \& Damasio 1982. 
siden neanderthalerne. ${ }^{5}$ Denne ekspansion bør ikke ses alene som en generel udvidelse af hjernemassen, men om en ganske bestemt ekspansion af især to områder. Det første er hjernebarken (cortex), primært pandelappen (præfrontal cortex), som kendetegnes ved de såkaldte 'eksekutive funktioner' som beslutning, planlægning, kritisk sans, personlighed, social adfærdskontrol mv. Det andet område er cerebellum, som har med kontrol over kroppens motorik at gøre. Det har givet en betydelig større præcision i kropslige bevægelser, herunder evnen til at fremstille redskaber. Begge disse udvidelser hænger nøje sammen med øget social læring eller med andre ord kultur! ${ }^{6}$

Neurologen Terrence Deacon har påvist at når bestemte hjerneområder udvider sig forholdsvist stort i forhold til resten af hjernen og kroppen, har disse områder en tendens til at invadere de andre hjerneområder og får derved direkte kontrol over dem. Denne iagttagelse kaldes ‘Deacons regel' (Deacon 1990; Laland 2017, 145). Således gav cerebellums udvidelse betydelig større kontrol over vores kæber, ansigter, tunger, stemmebånd og hænder. Denne iagttagelse falder godt i tråd med Merlin Donalds hypotese om 'cognitive governance', hvilket bygger netop på konstateringen af især den præfrontale cortex' udvidelse med efterfølgende styring af de motoriske hjerneområder. Denne styring var nøglen til den mimetiske revolution, hvormed mennesket var i stand til at bruge kroppen i et hidtil ukendt omfang til kommunikation (Donald 1991, 162ff.; 2001, 46ff.).

\begin{tabular}{|l|l|l|}
\hline Australopithecus & $4-1,2$ millioner år siden & $390-500 \mathrm{~cm}^{3}$ \\
\hline Homo habilis & $2,1-1,5$ millioner år siden & $510-660 \mathrm{~cm}^{3}$ \\
\hline Homo erectus & $\begin{array}{l}1,9 \text { millioner }-70.000 \text { år si- } \\
\text { den }\end{array}$ & $\begin{array}{l}850 \text { (tidlig) }-1100 \text { (sent) } \\
\mathrm{cm}^{3}\end{array}$ \\
\hline Homo neanderthalensis & $350.000-40.000$ år siden & $1200-1900 \mathrm{~cm}^{3}$ \\
\hline Homo sapiens & $300.000-\mathrm{i}$ dag & $950-1800 \mathrm{~cm}^{3}$ \\
\hline
\end{tabular}

Skema 2. Homininlinjens hjernestørrelser. Baseret på "Human Evolution", Wikipedia, 23.09.2017 og Leonard et al. 2003, 8 .

5 Diskussionen om hjernes udvidelse er præget af megen usikkerhed angående hjernestørrelsen i forhold til kropsvægt og - ikke mindst - hvilken betydning hjernens størrelse har for et væsens intelligens. For at gøre det endnu værre kommer race-debatten - som oftest skjult - ind i billedet. Se de tidlige metodologiske overvejelser fra 1970'ernes diskussioner (Olivier et al. 1978; Zindler 1978). Kevin Laland tager det forbehold, at diskussionen om hjernens størrelse skal bruges med omhu. Som eksempel fremhæver han hvalens betydelige større hjerne end menneskets, men som bruges mest til at navigere dens enorme krop snarere end at udvide dens intelligens (Laland 2017, 148. 343 n. 7). Hvis man korrelerer hjernestørrelse med kropsvægt, er det også bemærkelsesværdigt, at det er enkelte fugle som fx krager og ravne i corvides-familien, der kommer tættest på mennesker (1:39 vs. $1: 40)$.

6 Det skal lige nævnes, at der er andre arter som har udvidede hjerner, øgede kognitive evner og som er kulturmagere. Det gælder fx visse fugle (corvider og papegøjer) og cetaceaner (hvaler og delfiner). Råger fx har relativt set samme hjernestørrelse som chimpanser, og som Laland påpeger udviser de kompleks social adfærd, perspektivtagning, innovation og kulturel transmission (Laland 2017, 148). Men, fortsat if. Laland, er der klare begrænsninger i hver af disse arter på, hvor langt de kan udvikle sig i forhold til teknologisk udvikling. 


\section{Kevin N. Laland konkluderer:}

[I]n some primate lineages characterized by large brains and complex social groups, a critical threshold in reliance on socially learned behavior has been reached. Once this threshold had been passed, mutually reinforcing selection for increased brain size, diverse cognitive abilities, and further reliance on social learning and innovation ensued, mediated by conferred increases in longevity and diet quality. Large brains are certainly not a prerequisite for social learning, but they may well support more efficient, higherfidelity forms of social learning, thereby allowing copying over greater distances, highprecision imitation, cross-modal integration of perceptual and motor information, the computational power to implement sophisticated social learning strategies, and more. ... Consistent with this, those brain regions that have expanded during the course of human evolution include regions associated with social learning, imitation, innovation, and tool use (Laland 2017, 147-148).

Disse evner synes at være begrænset til primater med de største hjerner.

Inden for evolutionsbiologien, fysisk antropologi og forhistorisk arkæologi har man længe påpeget, at denne udvidelse hænger sammen med udviklingen af stenredskaber. Man gjorde allerede i slutningen af 1950'erne den iagttagelse, at udvidelsen af hjernebarken er et resultat af bl.a. udviklingen af stenredskaber og hverken omvendt eller parallelt. Denne iagttagelse blev fremført bl.a. ved en symposiepublikation redigeret af J. N. Spuhler. I et bidrag til denne argumenterede S. L. Washburn følgende:

Tools changed the whole pattern of life bringing in hunting, cooperation, and the necessity for communication and language. Memory, foresight and originality were favored as never before, and the complex social system made possible by tools could only be realized by domesticated individuals. In a very real sense, tools created Homo sapiens (Washburn 1959, 31).

De fleste er ikke klar over, at antropologen Clifford Geertz baserede sin religionsforståelse på bl.a. disse indsigter. I sine tidlige essays i 1960'erne “The Growth of Culture and the Evolution of Mind" (Geertz 1962/1973) og "The Impact of the Concept of Culture on the Concept of Man" (Geertz 1966a/1973) diskuterede Geertz, hvordan disse indsigter skulle forstås af antropologer. ${ }^{7}$ I det førstnævnte essay skrev han følgende:

Most crucially, it then becomes apparent that not only was cultural accumulation under way well before organic development ceased, but that such accumulation very likely played an active role in shaping the final stages of that development. Though it is apparently true enough that the invention of the airplane led to no visible bodily changes, no alterations of (innate) mental capacity, this was not necessarily the case for the pebble tool or the crude chopper, in whose wake seems to have come not only more erect stature, reduced dentition, and a more thumb-dominated hand, but the expansion of the human brain to its present size. Because tool manufacture puts a premium on manual skill and foresight, its introduction must have acted to shift selection pressures so as to favor the rapid growth of the forebrain as, in all likelihood, did the advances in

7 Se min analyse af Clifford Geertz' betydning for den kognitive religionsvidenskab i Geertz 2013a. 
social organization, communication, and moral regulation which there is reason to believe also occurred during this period of overlap between cultural and biological change. Nor were such nervous system changes merely quantitative; alterations in the interconnections among neurons and their manner of functioning may have been of greater importance than the simple increase in their number. Details aside, however and the bulk of them remain to be determined - the point is that the innate, generic constitution of modern man (what used, in a simpler day, to be called "human nature") now appears to be both a cultural and a biological product.... (Geertz 1962/1973, 67)

Således kan man i det mindste konstatere, at mennesket aldrig har været uden kultur. Men man kan også konstatere, at der på ingen måde kan være tale om et biologisk væsen, blot overtrukket med kultur ligesom chokoladen på marcipanbrød. Kulturen er derimod konstituerende for det moderne menneske og har været det fra et meget tidligt tidspunkt i den hominine evolution.

Det kan måske virke lidt utroligt, at hjernens udvidelse angiveligt skulle være et resultat af det at slå nogle sten mod hinanden. Men det er ikke så nemt at lave stenredskaber. ${ }^{8}$ Den tyske arkæolog Miriam Noël Haidle har udført en række interessante analyser af, hvilke kognitive egenskaber der skal til for at lave stenredskaber. ${ }^{9}$ Den meget sigende titel "How to Think a Simple Spear" (Haidle 2009) peger på formålet med analysen. I en omarbejdet habilitationsskrift har Haidle udgivet en mere omfattende analyse med titlen How to Think Tools? (2012). ${ }^{10}$ Hvad Haidle har gjort, er at identificere de kognitive enheder eller brøkdele, som indgår i udfærdigelsen af fx et spyd i en påtænkt problem-problemløsnings-sekvens. Disse enheder kalder Haidle 'kognigrammer' (2009: 60), som identificeres ved følgende procedure: Identificér individets fokus på behov og det redskab, som kan opfylde behovet; identificér individets perceptioner af behov og problemer, som så sætter processen i gang; identificér de mindste handlingsenheder, der skal til for at løse problemet; identificér effekterne af aktiv kontrol i forhold til redskabet; og til sidst identificér sekvenserne i tanke-oghandlings-processen. I et studium af, hvad der skal til for at lave et spyd, sammenligner Haidle følgende kategorier af kognigrammer: dem, som en chimpanse skal bruge for at knække nødder med en sten og til at spidde en lille abe med; dem, som en hominin skal bruge for at lave det primitive oldowan-skæreredskab; og dem som en

8 Et spændende temanummer af Philosophical Transactions of the Royal Society B - Biological Sciences redigeret af Colin Renfrew, Chris Frith og Lambros Malafouris (2008) har samlet en række bidrag, som ser på, hvilken virkning redskaber har på hjernens fysiologi. Se eksempelvis Dietrich Stout et al., "Neural Correlates of Early Stone Age Toolmaking" (2008), Fiona Coward og Clive Gamble, "Big Brains, Small Worlds" (2008); Lambros Malafouris, "Between Brains, Bodies and Things: Tectonoetic Awareness and the Extended Self" (2008). En anden interessant publikation, som udkom i 1996, undersøger bl.a. abernes brug af redskaber (Russon et al. 1996). Se også Liénard \& Sørensen 2013; Keller \& Keller 1996.

9 Haidle 2009; 2010; 2012; Lombard \& Haidle 2012. Se det interessante temanummer i Current Anthropology (bd. 51, nr. S1, 2010) om arbejdshukommelse i arkæologisk perspektiv, hvor flere bidrag drejer sig om redskaber og kognition.

10 Dette imponerende værk er frit tilgængeligt på Eberhard Karls Universität Tübingen udgivet i en ny serie med titlen Cognitive Perspectives in Tool Behaviour (http://tobias-lib.uni-tuebingen.de/portal/cognitive-perspectives/?la=de). 
Homo heidelbergensis (ca. for 600.000 - eller måske endnu ældre - og ned til 200.000 år siden) skal bruge for at lave et spyd til at nedlægge vilde heste med i Schöningenegnen i Niedersachsen. De to førstnævnte ligner hinanden i antallet af kognigrammer (ca. 15 enheder); men den afgørende forskel er, at oldowan-redskabsproduktionen kræver brug af to andre redskaber til at lave et skæreredskab. Dette ekstra skridt, dvs. at bruge et redskab for at lave et redskab for at opnå et mål, udgør en markant kognitiv forøgelse i forhold til chimpansens brug af en sten for at knække en nød. Når man ser på antallet af kognigrammer samt de mellemliggende faser, der skal til for at lave et spyd, er der sket en kolossal eksplosion af kognigrammer (godt og vel 29 med næsten lige så mange underliggende sub-rutiner), hvilket tyder på en eksponentiel forøgelse af kognitiv formåen.

Denne eksponentielle forøgelse af kognitiv formåen, som hænger sammen med stenredskabsproduktion, forudsætter, at redskabsmageren lærer fra sig i en bestemt kulturel og social sammenhæng og derudover er i stand til at danne sig et kognitivt begreb om, hvad han er i gang med. Man skal kunne se slutresultatet for sig for at være i stand til at udføre de enkelte handlingssekvenser. Som ovenfor antydet drejer det sig for Clifford Geertz om en videregivelse af kulturelle opskrifter, regler og instruktioner. Det, som kendetegner mennesket, er, at vi bevidst overfører kulturer og traditioner til hinanden og til yngre generationer. Filosoffen Kim Sterelny betragter denne bevidste læren fra sig som menneskelig unikt (2012), ligesom Kevin Laland lægger afgørende vægt på eksistensen af en symbolsk kompetence og derved muligheden for konceptuel tænkning som særlig for den hominine linje fra i al fald Homo ergaster og fremkomsten af acheuliansk kultur for ca. 1,7 millioner år siden (2017).

\section{Hvorfor og hvorfra er religion kommet?}

Jo mere man følger med i de seneste landvindinger vedrørende arternes evolution, desto mere fascinerende og udfordrende bliver studiet af religionens oprindelse. Jeg har forsøgt at vise, hvordan disse landvindinger kan bidrage til religionsvidenskab (Geertz 2008a; 2010b; 2011b; 2013a), senest i en antologi om oprindelsen til religion, kognition og kultur (Geertz 2013b). I et kapitel med overskriften "Whence Religion?" (Geertz 2013c) har jeg med udgangspunkt i den eksperimentelle neuropsykologi forsøgt at beskrive, hvorfor, hvorfra og hvornår religion er opstået (derfor begrebet 'whence', som rummer alle tre hv-spørgsmål). ${ }^{11}$

For at kunne finde frem til, hvornår religion er opstået, skal man identificere, hvilke egenskaber der skal til, for at der overhovedet er tale om en religion. Og her skal jeg lige gøre opmærksom på, at jeg taler om 'proto-religiøsitet' og ikke om fuldfærdige religiøse systemer. Men religion består af forskellige bestanddele, som hidrører fra forskellige evolutionære sammenhænge, så det er der i grunden ikke noget mærkeligt i. Hvorom al ting er, må disse systemer være kommet et eller andet sted fra, og det sted må have været meget primitivt. Pascal Boyer var inde på de egenska-

11 Resten af dette bidrag er løst baseret på Geertz 2013c, 31ff. 
ber, der gør religion naturlig for os (han taler ikke om proto-religiøsitet, men om hvorfor religiøse ideer er naturlige og hvordan de bliver husket og videreført fra generation til generation). Der er tale om seks egenskaber: 1) en overudviklet social intelligens, 2) evnen til at identificere eventuelle samarbejdspartnere og sociale bedragere eller snyltere, 3) et repertoire af medfødte moralske følelser, 4) evnen til at udvikle og bruge signaler, som enten er svære eller umulige at simulere eller forfalske, 5) evnen til selvbedrag og 6) emotionel tilfredsstillelse ved småsnak og sladder (Boyer 2000, 203-204).

Med udgangspunkt i neuropsykologisk forskning og eksperimentel psykologi mener jeg, at vi kan nøjes med fire grundlæggende egenskaber: 1) en finjusteret socialkognition, 2) behovet for at kommunikere og samarbejde, 3) en selv-bedragerisk hjerne og 4) en overtroisk hjerne med en tendens til ekstraordinære mentale og emotionelle oplevelser. Jeg vil i det følgende gennemgå dem hver for sig.

\section{1) En finjusteret socialkognition}

Neurolog-parret Chris og Uta Frith har i en række arbejder udført adfærdseksperimenter, hjernescanninger og andre undersøgelser angående den menneskelige socialkognition. I en review-artikel fra 2010 ("The Social Brain: Allowing Humans to Boldly Go Where No Other Species Has Been") opregner de tolv kendetegn, som jeg dog ikke vil gennemgå her. Men de vigtigste kendetegn er vores evner til at kommunikere, tune ind på hinanden (også motorisk), afkode signaler fra og om hinanden, specielt med henblik på tydningen af intentioner og mål, lære fra os, sætte os i andres sted, samarbejde, nære empati, være altruistisk og interesseret i eget renommé og indflydelse. Vi bruger mange ressourcer på at opdatere vores viden om og forventninger til hinanden. Det ligger dybt i os at være prosociale og samarbejdsvillige. Frith og Frith kalder det "our default mode of behavior when we are not thinking very deeply about what we are doing" (Frith \& Frith 2010, 171).

To forhold er helt centrale: vores evne til at læse hinandens intentioner og tanker samt hjernens grundlæggende funktion.

Hvad førstnævnte angår, er der tale om 'mentalisering' eller 'theory of mind', som sætter os i stand til at forestille os, hvad andre personer ved og - ikke mindst - hvad de ikke ved. Denne evne gør os i stand til at kommunikere og manipulere med andre mennesker. Vi bruger signaler, empati, emotionel smitte, efterabning og mange andre teknikker til at finjustere vores 'tankelæsnings-evner'. Nyfødte børn lærer ret hurtigt at opfange sociale signaler, som efterhånden gør dem i stand til at lære sproget og tilegne sig vigtige sociale kompetencer. Så snart de i løbet af de to første leveår lærer at se på egne, indre mentale og følelsesmæssige tilstande, 'inner mindsight' som psykolog Nicholas Humphrey kalder det, udnytter barnet evnen til at forstå andre mennesker. Man lærer med andre ord at udøve psykologisk tolkning (Humphrey 1986/2002, 94). Således kendetegnes vores bevidsthed ikke alene ved selvbevidsthed, men også og næsten samtidig bevidsthed om andre mennesker. Vi tænker ikke kun om os selv, men også om andre.

Hvad hjernen angår, så har den som primær funktion at finde mening i tilværelsen. Det gør den på en bestemt måde, nemlig gennem udvikling af modeller af verden (de 
indre, eksterne og sociale miljøer), som danner grundlaget for hjernens forudsigelser om, hvad der sker i nuet, og hvad der skal ske i næste nu (predictive processing). Vores hjerne er langt foran vores bevidste og ubevidste adfærd og langt foran vores sanser. Vores oplevelse af verden er ikke en oplevelse af selve verden (uanset om vi taler om kroppens funktioner og signaler, interne mentale og følelsesmæssige tilstande eller mødet med fænomener og væsner i naturen eller i omgangen med det sociale miljø), men en oplevelse af hjernens forventninger til og forestillinger om verden. Som Chris Frith skrev i sit værk Making Up the Mind (Frith 2007):

Everything we know, whether it is about the physical or the mental world, comes to us through our brain. But our brain's connection with the physical world of objects is no more direct than our brain's connection with the mental world of ideas. By hiding from us all the unconscious inferences that it makes, our brain creates the illusion that we have direct contact with objects in the physical world. And at the same time our brain creates the illusion that our own mental world is isolated and private. Through these two illusions we experience ourselves as agents, acting independently upon the world. But, at the same time, we can share our experiences of the world. Over the millennia this ability to share experience has created human culture that has, in its turn, modified the functioning of the human brain. (Frith 2007, 17)

Når det drejer sig om vores omgang med andre mennesker, bruger hjernen samme forudsigelsesmekanisme. Vi skal således hele tiden opdatere vores forventninger til og forudsigelser om hinandens intentioner, motivationer, mentale og følelsesmæssige tilstande osv. ${ }^{12}$

\section{2) Behovet for at kommunikere og samarbejde}

Lige fra fødslen bliver barnet bombarderet med indtryk fra mor og far, søskende og andre i nærheden. Man forsøger helt ubesværet og ubevidst at lære barnet at være opmærksom på sociale signaler. Det gør man gennem øjenkontakt, ansigtsudtryk, specielle lyde og gestikulationer, knus og kys og alt, hvad der hører til at nusse omkring et lille barn. Gennem amning overfører moderen ikke alene livgivende næring, men også følelsesmæssig næring, således at barnet føler sig følt af andre mennesker (Siegel 2001; Cozolino 2002). Alle disse og mange andre rutiner har to formål: at lære barnet at forstå og håndtere egne interne tilstande og at lære barnet at være opmærksom på sociale tegn, som vil gøre det i stand til at blive kulturelt og socialt kompetent. Merlin Donald taler om opmærksomhedsmarkører, som før eller senere leder barnet hen til kulturens hjerte og det fælles netværk af følelser, viden og hukommelse, der er kulturens kognitive omdrejningspunkt (Donald 2001, 255; Geertz 2011a).

I de første år er denne socialisering baseret på efterligning og forældrenes billigelse og misbilligelse. Men den bliver efterhånden mere systematisk gennem fortællinger,

12 Se Geertz 2010b; 2011d; 2013c, og Schjoedt et al. 2013b, som præsenterer, hvorledes dette neurologiske paradigme kan bruges i den kognitive religionsvidenskab. Paradigmet kobles sammen med eksperimenter, der viser, hvordan rituel adfærd dræner vores kognitive ressourcer og dermed gør det muligt for andre at manipulere med vores opmærksomhed og fortolkninger (Nielbo \& Sørensen 2011; Nielbo et al. 2013; Schjoedt et al. 2013a), men også forøger gruppesamarbejde (Mitkidis et al. $2013 ; 2014)$. 
samtaler, formaninger, overtalelse, magt, straf og/eller vold. Systematisk uddannelse tager over, og når man bliver voksen, findes der desuden institutioner som politiet, religiøse og politiske ritualer og offentlige begivenheder, aktiviteter i lokalområdet, indvielsesritualer osv., som sikrer, at man har tilpasset sig samfundets normer og idealer. Vi har de kognitive egenskaber til at tage imod disse socialiseringsinstrumenter. Og vi har ikke alene evnen til, men også et stærkt behov for at påtage os et verdenssyn (Geertz 1966b/1973; Koltko-Rivera 2004).

Det specifikt symbolske sprog er ifølge Donald opstået som led i en forøgelse af vores behov for og evner til at kommunikere med andre mennesker. Vi bruger sproget til at forvandle imaginære verdener til virkelighed, håndtere imaginære væsener og gøre dem personlige og gøre fortællinger af imaginær art til en del af kroppen og bevidstheden. Som jeg har skrevet andetsteds:

Religious narrative promulgates, extrapolates and investigates the significance of virtual worlds in real time contexts while at the same time refining them in all their majestic virtuality. Religious narrative provides paradigms for human identity thereby providing narrative governance of human cognition and emotion (Geertz 2011a, 9).

Ikke mindst bruger vi sladder og hyggesnak til at holde øje med hinanden og til kontinuerligt at formulere vores egen identitet og pleje vores renommé og indflydelse (Dunbar 1996; Ochs \& Capps 1996; Geertz 2004b \& 2011c). I forhold til renommé kan denne interesse forklares ved 'kostbare-signaler-teorien' fremført af blandt andre Richard Sosis og Joseph Bulbulia (fx Bulbulia \& Sosis 2011; Bulbulia 2004a, 2004b). Ifølge denne teori har religiøs adfærd haft en selektiv fordel, fordi den sender vigtige sociale signaler, som er svære at snyde sig til. De er kostbare enten i tid, værdi eller kropslige og andre markeringer. Signalerne hjælper gruppen til at opdage folk, som ikke bidrager til gruppens bedste og blot nyder godt af andres altruistiske adfærd ('free riders' eller snyltere og gratister, som det hedder). Mange psykologiske og økonomiske eksperimenter viser, at vi bliver vrede og gerne straffer sociale snydere. Den eksperimentelle psykolog Joseph Henrich taler ligefrem om CRED, dvs. 'credibility enhancing displays', hvor man benytter sig af markører, der signalerer, at man er en troværdig partner eller borger. Ritualer er et sådant middel (Henrich 2009). Den tidligere omtalte Scott Atran definerer religion netop i forhold til kostbare-signaler-teorien:

Roughly, religion is (1) a community's costly and hard-to-fake commitment (2) to a counterfactual and counterintuitive world of supernatural agents (3) who master people's existential anxieties, such as death and deception (Atran 2002, 4).

\section{3) En selv-bedragerisk hjerne}

Vi bliver nødt til at tage vores lettroenhed alvorligt, dvs. vores tendens til illusion, selvbedrag og konfabulation (Hirstein 2005). Vi er faktisk utrolig let- og godtroende. Vi glædes og undres over tilsyneladende mirakler og er nemme ofre for taskenspillere. Vi ser desuden det, vi gerne vil se, og overser det, vi burde se. Vi producerer illusioner og selvbedrag. Vi bortforklarer, og vi bliver vrede over andres fejl, men er overbærende over for egne fejl. Vi er selvtilfredse, selvgode og skråsikre. Vi har mange teknikker til at holde det ukendte og farlige på afstand (Burton 2008). Vi er 
eksistentielle illusionister (Bering 2006; 2011), og vi synes at have en intuitiv accept af sympatetisk magi (Hood et al. 2010).

Neuropsykologen Cordelia Fine har i bogen A Mind of Its Own (2006) skitseret, hvordan vores hjerne virker. Kapiteloverskrifterne er ret sigende: Den forfængelige hjerne (vain brain) som er selvoptaget og overmodig. Den emotionelle hjerne (emotional brain) som er styret af vores følelser. Så vores hjerne er umoralsk (immoral brain) i den forstand, at den gennem efterrationaliseringer bortforklarer. Hjernen producerer illusioner og delusioner (deluded brain) og er stædig (pig-headed brain). Den er også hemmelighedsfuld (secretive brain) og er drevet af ubevidste motivationer. Men den er også svag (weak-willed brain), som når man overgiver sig til tankestrømmens magt. Hjernen er også fordomsfuld (bigoted brain) og ser verden og især andre mennesker gennem stereotyper og fordomme. Og endelig er hjernen sårbar (vulnerable brain) og manipulerer med informationer.

Først og fremmest er hjernen som allerede pointeret en forudsigelsesmaskine. Vores forventninger styrer vores oplevelser, erfaringer og sanser. Et nyt felt, som hedder 'neuromagi', har gennem forskellige eksperimenter vist, hvor nemt det er at snyde hjernen og sanserne (Macknik et al. 2010). Det, vi ser, er ikke verden, som den er, men verden som den simuleres af hjernen. Det er noget, som tryllekunstnere og religiøse specialister (mere eller mindre bevidste) ved noget om. Man udnytter "the fact that your brain does a staggering amount of outright confabulation in order to construct the mental simulation of reality known as 'consciousness'“ (Macknick et al. 2010, 9). Der er faktisk gode grunde til, som neurolog Kathleen Taylor understreger i bogen Brainwashing: The Science of Thought Control (2004), at være opmærksom på, hvor let påvirkelige vi er.

Sammenfattende konkluderer jeg, at disse egenskaber, i kombination med den ekstreme socialitet, som i kraft af kulturel udvikling, men netop ikke forankret i vores basale abebiologi, kendetegner vores art, frembringer:

.... creature that can be desperately dependent yet incredibly independent, whimsical yet determined, self-serving yet startlingly altruistic, appallingly credulous yet highly sceptical, debilitatingly insecure yet supremely confident, devious yet true, devastatingly violent yet incredibly peaceful and forgiving - a curious and fearful creature inextricably woven into collective webs of symbolic, virtual worlds (Geertz 2013c, 39).

\section{4) En overtroisk hjerne med en tendens til ekstraordinære mentale og emotionelle oplevelser}

Jeg er kommet til den konklusion, at vi er overtroiske som udgangspunkt. Overtro er et problematisk begreb, fordi mange såvel religiøse som ikke-religiøse bruger begrebet som en negativ betegnelse for de andres overbevisninger og adfærd. Jeg anvender begrebet til at betegne ikke alene de tvungne, stereotype handlinger, som man fx bruger, inden man slår til golfbolden med en kølle, eller når fx nybagte mødre hænger barnets bleer på tørresnoren på en bestemt måde, men også deciderede magiske 
handlinger. ${ }^{13}$ Det er svært at afgrænse forskellene mellem overtro, magi og religion. Jeg mener, at de er tre sider af samme sag, nemlig antagelser om eller troen på modintuitiv kausalitet. Med modintuitiv mener jeg kausalitet, som overgår fysikkens love. Psykolog Bruce M. Hood kalder det vores 'supersense' eller oversanselige fornemmelser, hvilket vil sige, at vi har en naturlig tendens til at opleve bagvedliggende usynlige mønstre, kræfter, energier og væsener, som vi forklarer overnaturligt (2009, $\mathrm{x})$.

Dertil kommer, som allerede omtalt i afsnittet om den følelsesladede abe, at vi har en naturlig tendens til ekstraordinære mentale og emotionelle oplevelser. Her mener jeg mystiske oplevelser, overnaturlige fornemmelser ('sensed presence'), åndebesættelse, visioner, auditioner, hallucinationer, gruppehysteri osv. (se Cohen 2007; Targ et al. 2000; Taves 2009; Wulff 2000). Der er mange studier af mennesker med mentale lidelser og sygdomme, der rapporterer om mærkelige oplevelser; åndebesættelsesfænomenet der kan forklares som multipel personlighedsforstyrrelse (MPD); folk som hører stemmer, der kan forklares som skizofreni; eller voksne mennesker som 'pludselig husker', at de er blevet udsat for sataniske ritualer som babyer, hvilket kan forklares som falske erindringer. Andre studier undersøger epilepsi som mulig årsag til mystiske oplevelser. ${ }^{14}$

Der er ingen tvivl om, at studier af dissociativ adfærd kan fortælle os noget om vores tendenser til overnaturlige oplevelser. Jeg siger ikke, at religiøse oplevelser er udtryk for sindslidelser, selvom der utvivlsomt er mange, hvor det er tilfældet, men at disse studier peger på nogle hjerneområder og -funktioner, som i ikke-sygelige tilfælde godt kan være på spil i religiøse sammenhænge. Den kognitive antropolog Tanya Luhrmann har rigtigt påpeget, at disse oplevelser er styret af sociale og kulturelle forventninger, der fungerer som 'sensory overrides', dvs. at de styrer sanserne. Som hun skrev: "the local theory of mind... and local practices of mental cultivation will affect both the kinds of unusual sensory experiences that individuals report and the frequency of those experiences" (Luhrmann 2011, 72). Denne konklusion støttes også af Nicholas P. Spanos, som taler om disse fænomener som 'socialkognitive' i den forstand, at de psykologiske oplevelser styres af sociale forventninger (Spanos 1996).

Men vi må ikke glemme, at der også er tale om neurologiske mekanismer, som kan være på spil i forbindelse med religiøse oplevelser. Disse mekanismer drejer sig om stimulering af det limbiske system (følelsesområderne i hjernen), hjernens monoaminergiske transmittere (dopamin, serotonin, adrenalin osv.), hjernens modulatorer, som bl.a. rummer hjernens morfiner, der kaldes endorfiner; det som kaldes 'saliency pathways', som er systemer der tildeler betydning til forskellige sanseindtryk, og endelig placebo- og nocebo-effekter. I forbindelse med sindslidelser og -sygdomme har man registreret ubalancer i disse systemer. Vigtigt for os i denne sammenhæng er, at

13 Se Boyer \& Liénard 2006; Damisch et al. 2010; Liénard \& Boyer 2006; Jahoda 1969; Vyse 1997. Se også Jesper Sørensens omfattende arbejde med de kognitive mekanismer bag magiske handlinger (fx Sørensen 2001; 2007b; 2007c).

14 Se en oversigt over disse fænomener og studier i Kihlström et al. 1990; Spanos 1996. 
man også gennem religiøse ritualer kan stimulere og rykke balancen i disse systemer. ${ }^{15}$ Det er utrolig nemt gennem deprivation eller overstimulering at fremtvinge ekstraordinære oplevelser (se Andersen et al. 2014; Wulff 1991, 61-88). Således reguleres neurale systemer gennem ritualer og social adfærd. Gennem ritualiseringen af kroppen stimuleres forskellige mentale og emotionelle tilstande.

Ritualer og modificeringen af disse systemer spiller en central rolle i religiøse terapeutiske og alternative terapeutiske systemer verden over (Krippner \& Achterberg 2000). Ikke mindst i den forbindelse ser man som oftest den såkaldte placebo-effekt. ${ }^{16}$ Lægen Ted J. Kaptchuk taler om alternative terapier som 'placebo-dramaer', som er med til at forøge patienternes 'magiske forventninger' (2002).

\section{Hvornår er religion kommet?}

Det er min påstand, at udviklingen af den præfrontale cortex bragte en række andre ting med sig, bl.a. hjernelidelser og psykoser samt forøgede spekulationer, bekymringer, frygt og angst. Jeg mener, at vores overtroiske, magiske tænkning også kom med, fordi vi nemt bliver skræmte ('spooked'), og vores fantasier får frit spil. Ud fra dette perspektiv kan Boyers modintuitive ideer og Barretts overstimulerede agens-detektions-mekanisme umuligt alene forklare religionens opståen, blandt andet fordi de kun fokuserer på et element blandt andre og ikke tilstrækkeligt inddrager selve hjerneudviklingen. Ud over de neuropsykologiske træk, som ovenfor påpeget, er der en række andre ting, der skal med.

Men hvornår finder man væsener i homininlinjen, som udviser disse træk? Lad os først opsummere, hvilke træk vi leder efter:

1. Der skal være en hel del kognitive og sociale funktioner til stede, for at man kan dele normative ideer og adfærd med andre.

2. Der skal desuden en selvbevidsthed til, og ikke kun bevidst intentionalitet, som andre dyr har.

3. Der skal være selvrefleksion og identitet.

4. Der skal være empati og sympati.

5. Man skal kunne kommunikere symbolsk.

6. Der skal være en social gruppe, som deler værdier og normer.

7. Der skal være sociale strukturer eller mekanismer til at løse fælles problemer (altruisme, alliancer, samarbejde osv.)

8. Man skal kunne overføre viden fra den ene generation til den næste.

9. Autoritet, kontrol og moral skal være til stede, for at samfundet kan fungere. adfærd, fx Schjoedt et al. 2008; 2009; 2011; Jegindø 2012; Jegindø et al. 2013a; 2013b; Konvalinka et al. 2011; Xygalatas et al. 2011; 2013a; 2013b.

16 Se Andersen 2011; Benedetti et al. 2011; Benedetti 2009; 2011; Vase \& Petersen 2011. 
10. Man skal kunne bruge ritualer (ikke blot rituel adfærd som hos andre dyr) til bestemte formål som synkronisitet, emotionel effervescens, identitetsskabelse osv.

11. Overtro, oversanselighed og en fornemmelse af bagvedliggende kræfter i naturen må sandsynligvis også have været til stede. ${ }^{17}$

Der er ikke plads til at gennemgå de arkæologiske vidnesbyrd. Jeg vil blot henvise til mit essay om temaet (Geertz 2013c, 25-29), og alene fremlægge konklusionerne her. Den art, der synes at udvise ovennævnte træk, er Homo erectus (1,8-0,2 millioner år siden), mere specifikt Homo heidelbergensis i perioden for mellem 600.000 og 400.000 år siden (Tattersall 2012, 135-143). Homo erectus havde store hjerner, og de så moderne ud (med en lidt anden positionering af den præfrontale cortex) med forøgede Brocasområder (og muligheden for sprog), sofistikerede træspyd, symbolsk adfærd og genstande, kontrol over ilden og dermed mulighed for madlavning (Wrangham 2009; Burton 2009), brug af primitive hytter, avancerede stenredskaber. De forlod det afrikanske kontinent og evnede at tilpasse sig meget forskellige miljøer. De havde meget avancerede teknologiske og kulturelle træk. Der er også tegn på rituel adfærd i forbindelse med de døde og symbolske genstande.

Det næste spørgsmål må blive: Hvordan så proto-religiøs adfærd ud dengang? Man kan ikke gå ud fra, at der er tale om veludviklede religiøse trossystemer, ej heller religiøse institutioner. Men man må forestille sig, at deres adfærd var tilpasset betingelserne i naturen og i menneskelivet, som er relevante for jæger-samler tilværelsen. Mit forslag til en sådan proto-religiøs adfærd er følgende:

1. Den vil afspejle den sociale gruppe centreret omkring bålet med de implicerede kønsmæssige domæner, social status og kontrol.

2. Den vil være optaget af sociale begivenheder som $\mathrm{fx}$ overgangsfænomener, seksualitet og den kvindelige biologiske cyklus og fertilitet.

3. Den vil være optaget af døden og de døde og sandsynligvis også af uheld og ondskab.

4. Den vil afspejle symbolsk tænkning ved brug af tegn og varsler og en fornemmelse af bagvedliggende kræfter i forbindelse med planter (ernæring og medicin), dyr (rovdyr, fangstdyr) og naturlige fænomener (storm, tørke, oversvømmelser, jordskælv, vulkaner).

5. Den vil gøre brug af magisk tænkning (sympatetisk og kontagiøs).

6. Der vil være brug af ritualer, dans, musik og/eller sang og forskellige metoder til at manipulere med krop og sind (faste, sult, påført smerte).

7. Den vil også være optaget af ændrede bevidsthedstilstande som drømme, visioner, hallucinationer osv.

8. Den vil udtrykke gruppens følelser, værdier, institutioner ( $f x$ redskabsproduktion) og fortællinger (også før-sproglige, mimetik).

17 For tilsvarende, men lidt anderledes lister, se Donald 2001, 139-148; Turner et al. 2017, 128-129, tabel 6.2 . 


\section{Konklusion}

Vores neurobiologi er tunet til at indgå i sociale sammenhænge med alt, hvad det indebærer på godt og ondt. Vores nervesystemer er særlig gearet til at være modtagelige over for andres indflydelse og manipulationer, herunder religiøse specialister, politikere og andre autoriteter. Disse egenskaber er blevet udviklet længe før, Homo sapiens kom til. Ja, vi deler sågar sociale og psykologiske egenskaber med de øvrige menneskeaber. Men med udvidelsen af hjernen i homininlinjen er der opstået en ekstraordinær situation, der har præget linjens forhold indbyrdes og i forhold til verden. Alle hjerner i dyreriget er forudsigelsesmaskiner, men vores er det i en særlig grad, både i den sociale verden og i virtuelle verdener. Jeg kan derfor konkludere, hvad jeg også tidligere har pointeret, at:

...we are intelligent apes that are highly emotional, easily spooked, very superstitious, extremely sensitive to social norms and virtual realities and equipped with nervous systems that are vulnerable to influence from conspecifics and their symbolic worlds. We and our brains are constantly predicting and constantly dwelling on the future in our attempts to navigate social and natural environments. Our brains fill in quite a bit, but our cultures are also in our brains and around them, filling in many more things (Geertz 2013c, 52).

\section{LITTERATUR}

Andersen, Lars Ole

2011 Før placeboeffekten: Indbildningskraftens virkning i 1800-tallets medicin, København: Museum Tusculanums Forlag.

Andersen, Marc N. et al.

2014 "Mystical Experience in the Lab", Method and Theory in the Study of Religion 26, 217-245. https://doi.org/10.1163/15700682-12341323

Atran, Scott

2002 In Gods We Trust: The Evolutionary Landscape of Religion, Oxford: Oxford University Press.

Barrett, Justin L.

2004 Why Would Anyone Believe in God?, Walnut Creek: AltaMira Press.

Benedetti, Fabrizio

2009 Placebo Effects: Understanding the Mechanisms in Health and Disease, Oxford: Oxford University Press.

Benedetti, Fabrizio

2011 The Patient's Brain: The Neuroscience behind the Doctor-Patient Relationship, Oxford: Oxford University Press.

Benedetti, Fabrizio et al.

2011 "How Placebos Change the Patient's Brain", Neuropsychopharmacology 36, 339-354. https://doi.org/10.1038/npp.2010.81

Bering, Jesse M.

2006 "The Folk Psychology of Souls", Behavioral and Brain Sciences 29, 453-498. https://doi.org/10.1017/S0140525X06009101

Bering, Jesse $\mathrm{M}$. 
2011 The Belief Instinct: The Psychology of Souls, Destiny, and the Meaning of Life, New York \& London: W. W. Norton \& Company.

Boyer, Pascal

2000 "Functional Origins of Religious Concepts: Ontological and Strategic Selection in Evolved Minds", The Journal of the Royal Anthropological Institute 6 (2), 195-214.

https://doi.org/10.1111/1467-9655.00012

Boyer, Pascal

2001 Religion Explained: The Evolutionary Origins of Religious Thought, New York: Basic Books.

Boyer, Pascal \& Pierre Liénard

2006 "Why Ritualized Behavior? Precaution Systems and Action Parsing in Developmental, Pathological and Cultural Rituals", Behavioral and Brain Sciences 29, 595-650. https://doi.org/10.1017/S0140525X06009332

Braun, Willi \& Russell T. McCutcheon, eds.

2000 Guide to the Study of Religion, London \& New York: Cassell.

Bulbulia, Joseph

2004a "Religious Costs as Adaptations That Signal Altruistic Intention", Evolution and Cognition 10 (1), $19-42$.

2004b “The Cognitive and Evolutionary Psychology of Religion”, Biology and Philosophy 19, 655-686. https://doi.org/10.1007/s10539-005-5568-6

Bulbulia, Joseph \& Richard Sosis

2011 "Signalling Theory and the Evolution of Religious Cooperation", Religion 41 (3), 363-388. https://doi.org/10.1080/0048721X.2011.604508

Burton, Frances D.

2009 Fire: The Spark That Ignited Human Evolution, Albuquerque: University of New Mexico Press.

Burton, Robert A.

2008 On Being Certain: Believing You Are Right Even When You're Not, New York: St. Martin's Press.

Clark, Andy

1997 Being There: Putting Brain, Body, and World Together Again, Cambridge \& London: The MIT Press.

Cohen, Emma

2007 The Mind Possessed: The Cognition of Spirit Possession in an Afro-Brazilian Religious Tradition, Oxford: Oxford University Press. https://doi.org/10.1093/acprof:oso/9780195323351.001.0001

Coward, Fiona \& Clive Gamble

2008 "Big Brains, Small Worlds: Material Culture and the Evolution of the Mind", Philosophical Transactions of the Royal Society B. Biological Sciences 363, 1969-1979. https://doi.org/10.1098/rstb.2008.0004

Cozolino, Louis J.

2002 The Neuroscience of Psychotherapy: Building and Rebuilding the Human Brain, New York \& London: W. W. Norton \& Company.

Crawford, Charles \& Dennis L. Krebs, eds.

2008 Foundations of Evolutionary Psychology, New York \& London: Lawrence Erlbaum Associates.

Damisch, Lysann et al.

2010 "Keep Your Fingers Crossed! How Superstition Improves Performance", Psychological Science 2010, 1-7.

Dawkins, Richard

1976 The Selfish Gene, Oxford \& New York: Oxford University Press.

2006 The God Delusion, London: Bantam Press.

Deacon, Terrence W.

1990 "Fallacies of Progression in Theories of Brain-Size Evolution", International Journal of Primatology 
11, 193-236. https://doi.org/10.1007/BF02192869

1997 The Symbolic Species: The Co-Evolution of Language and the Human Brain, London: Allen Lane The Penguin Press.

2003 "Multilevel Selection in a Complex Adaptive System: The Problem of Language Origins", in: Bruce H. Weber \& David J. Depew, eds., Evolution and Learning: The Baldwin Effect Reconsidered, Cambridge \& London: The MIT Press, 81-106.

Dennett, Daniel C.

2006 Breaking the Spell: Religion as a Natural Phenomenon, New York: Viking.

Donald, Merlin

1991 Origins of the Modern Mind: Three States in the Evolution of Culture and Cognition, Cambridge \& London: Harvard University Press.

2001 A Mind So Rare: The Evolution of Human Consciousness, New York \& London: W. W. Norton \& Company.

Dunbar, Robin

1996 Grooming, Gossip and the Evolution of Language, London: Faber and Faber.

Fine, Cornelia

2006 A Mind of Its Own: How Your Brain Distorts and Deceives, New York \& London: W. W. Norton \& Company.

Frith, Chris

2007 Making Up the Mind: How the Brain Creates Our Mental World, Oxford: Blackwell Publishing.

Frith, Uta \& Chris D. Frith

2010 "The Social Brain: Allowing Humans to Boldly Go Where No Other Species Has Been", Philosophical Transactions of the Royal Society B. Biological Sciences 365, 165-176. https://doi.org/10.1098/rstb.2009.0160

Geertz, Armin W

1990 “Mystik, visioner, ekstase og besættelse: En direkte linie?”, in: Per Bilde \& Armin W. Geertz, eds., Mystik - Den indre vej? En religionshistorisk udfordring, Aarhus: Aarhus Universitetsforlag, 107-138.

2004a "Cognitive Approaches to the Study of Religion", in: Peter Antes, Armin W. Geertz \& Randi Warne, eds., New Approaches in the Study of Religion, Berlin: Mouton de Gruyter 2004, Volume 2: Textual, Comparative, Sociological, and Cognitive Approaches, 347-399.

2004b “Sladder som religiøs fortælling - kognitive og socialpsykologiske betragtninger", in: Armin W. Geertz, Hans J. Lundager Jensen \& Jens Peter Schjødt, Det brede og det skarpe - Religionsvidenskabelige studier. En gave til Per Bilde på 65-årsdagen, København: Forlaget ANIS, 47-64.

2005 "Om religion og kognition - en forskningshistorisk og tematisk introduktion", Religionsvidenskabeligt Tidsskrift 46, 5-26.

2008a "Religion og kognition - En introduktion", Religion: Tidsskrift for Religionslærerforeningen for Gymnasiet og HF, september 2008 (3), 15-27.

$2008 \mathrm{~b}$ "From Apes to Devils and Angels: Comparing Scenarios on the Evolution of Religion", in: Joseph Bulbulia et al., eds., The Evolution of Religion: Studies, Theories, E Critiques, Santa Margarita: Collins Foundation Press, 43-49.

2010a "Too Much Mind and Not Enough Brain, Body and Culture: On What Needs to Be Done in the Cognitive Science of Religion", Historia Religionum. An International Journal 2, 21-37.

2010b "Brain, Body and Culture: A Biocultural Theory of Religion", Method and Theory in the Study of Religion 22 (4), 304-321. https://doi.org/10.1163/157006810X531094

2011a "Religious Narrative, Cognition and Culture: Approaches and Definitions", in: Armin W. Geertz \& Jeppe Sinding Jensen, eds., Religious Narrative, Cognition and Culture: Image and Word in the Mind of Narrative, Sheffield \& Oakville: Equinox Publishing, Ltd., 9-29.

2011b “Om religion og evolution. En introduktion", Religionsvidenskabeligt Tidsskrift 56, 23-60.

2011c "Religiøs narrativitet - et definitionsforsøg", in: Jeppe Sinding Jensen \& Armin W. Geertz, Religiøs narrativitet, kognition og kultur, Højbjerg: Forlaget Univers, 26-45.

2011d “Den mystiske mystik - Neurobiologisk, socialpsykologisk og kulturanalytisk set", Aksel 
Haaning \& Magnus Rissager, eds., Mystik - i filosofi, religion og litteratur. En antologi, Højbjerg: Forlaget Univers, 259-293.

2013a “The Meaningful Brain: Clifford Geertz and the Cognitive Science of Culture”, in: Dimitris Xygalatas \& William W. McCorkle, Jr., eds., Mental Culture: Classical Social Theory and the Cognitive Science of Religion, Durham: Acumen Publishing Ltd., 176-196.

2013c "Whence Religion? How the Brain Constructs the World and What This Might Tell Us about the Origins of Religion, Cognition and Culture", in: Armin W. Geertz, ed. 2013b, 17-70.

Geertz, Armin W., ed.

2013b Origins of Religion, Cognition and Culture, Durham: Acumen Publishing Limited.

Geertz, Armin W. \& Guðmundur Ingi Markússon

2010 “Religion Is Natural, Atheism Is Not: On Why Everybody Is Both Right and Wrong”, Religion 40 (3), 152-165. https://doi.org/10.1016/j.religion.2009.11.003

Geertz, Clifford

1962/1973 "The Growth of Culture and the Evolution of Mind", in: J. Scher, ed., Theories of the Mind, New York: The Free Press of Glencoe 1962, 713-740; genoptrykt i idem, The Interpretation of Cultures: Selected Essays, New York: Basic Books 1973, 55-83.

1966a/1973 "The Impact of the Concept of Culture on the Concept of Man", in: J.Platt, ed., New Views of the Nature of Man, Chicago: University of Chicago Press 1966, 93-118; genoptrykt in: idem., The Interpretation of Cultures: Selected Essays, New York: Basic Books 1973, 33-54. https://doi.org/10.1080/00963402.1966.11454918

1966b/1973 “Religion as a Cultural System”, in: M. Banton, ed. Anthropological Approaches to the Study of Religion, London: Tavistock Publications Ltd. 1966, 1-46; genoptrykt in: idem, The Interpretation of Cultures: Selected Essays, New York: Basic Books 1973, 87-125.

Goodman, Morris et al.,

1990 "Primate Evolution at the DNA Level and a Classification of Hominoids", Journal of Molecular Evolution 30, 260-266. https://doi.org/10.1007/BF02099995

Guthrie, Stewart Elliott

1993 Faces in the Clouds: A New Theory of Religion, Oxford \& New York: Oxford University Press.

Haidle, Miriam Noël

2009 "How to Think a Simple Spear", in: Sophie A. de Beaune, Frederick L. Coolidge \& Thomas Wynn, eds., Cognitive Archaeology and Human Evolution, Cambridge: Cambridge University Press, 57-73.

2010 "Working-memory Capacity and the Evolution of Modern Cognitive Potential", Current Anthropology 51, S149-S166. https://doi.org/10.1086/650295

2012 How to Think Tools? A Comparison of Cognitive Aspects in Tool Behavior of Animals and During Human Evolution, Tübingen: Eberhard Karls Universität Tübingen.

Henrich, Joseph

2009 "The Evolution of Costly Displays, Cooperation and Religion: Credibility Enhancing Displays and Their Implications for Cultural Evolution", Evolution and Human Behavior 30, 244-260. https://doi.org/10.1016/j.evolhumbehav.2009.03.005

Hirstein, William

2005 Brain Fiction: Self-Deception and the Riddle of Confabulation, Cambridge \& London: The MIT Press.

Hood, Bruce M.

2009 SuperSense: Why We Believe in the Unbelievable, New York: HarperOne.

Hood, Bruce M., Katherine Donnelly, Ute Leonards \& Paul Bloom

2010 "Implicit Voodoo: Electrodermal Activity Reveals a Susceptibility to Sympathetic Magic", Journal of Cognition and Culture 10, 391-399. https://doi.org/10.1163/156853710X531258

Humphrey, Nicholas

1986/2002 The Inner Eye. London, Faber and Faber Ltd., 1986; genoptrykt, Oxford: Oxford University Press, 2002.

Jahoda, Gustav 
1969 The Psychology of Superstition, London: Allen Lane The Penguin Press.

Jegindø, Else-Marie Elmholdt

2012 Pain and Coping in the Religious Mind, PhD dissertation, Aarhus: Aarhus University.

Jegindø, Else-Marie Elmholdt et al.

2013a "Pain and Sacrifice: Experience and Modulation of Pain in a Religious Piercing Ritual", International Journal for the Psychology of Religion 23 (3), 171-187. https://doi.org/10.1080/10508619.2012.759065

2013b “Expectations Contribute to Reduced Pain Levels During Prayer in Highly Religious Participants", Journal of Behavioral Medicine 36, 413-426. https://doi.org/10.1007/s10865-012-9438-9

Jensen, Jeppe Sinding

2003 "Pascal Boyer: Den ganske historie om al religion (nogensinde)", Religionsvidenskabeligt Tidsskrift 43, 53-69.

2009 "Religion as the Unintended Product of Brain Functions in the 'Standard Cognitive Science of Religion Model': On Pascal Boyer, Religion Explained (2001) and Ilkka Pyysiäinen, How Religion Works (2003)", in: Michael Stausberg, ed., Contemporary Theories of Religion: A Critical Companion, Abingdon \& New York: Routledge, 129-155.

Jensen, Peter K. A.

2004 Da mennesket blev menneske, København: Gyldendal.

Kaptchuk, Ted J.

2002 "The Placebo Effect in Alternative Medicine: Can the Performance of a Healing Ritual Have Clinical Significance?" Annals of Internal Medicine 136 (11), 817-825. https://doi.org/10.7326/0003-4819-136-11-200206040-00011

Keller, Charles M. \& Janet Dixon Keller

1996 Cognition and Tool Use: The Blacksmith at Work, Cambridge: Cambridge University Press.

Kihlstrom, John F., Douglas J. Tataryn \& Irene P. Hoyt

1990 Dissociative Disorders. Orpindeligt udateret, ikke-redigeret manuskript, skrevet i 1990, som er on-line på (http://socrates.berkeley.edu/ kihlstrm/ Sutker93.htm). Udgivet i redigeret form in: P. J. Sutker \& H. E. Adams, eds. Comprehensive Handbook of Psychopathology, 2. ed., New York: Plenum, 1993, 203-234 og opdateret in: idem., eds., Comprehensive Handbook of Psychopathology, 3. udg., New York: Kluwer Academic \& Plenum, 2001, 259-276.

Koltko-Rivera, Mark E.

2004 "The Psychology of Worldviews", Review of General Psychology 8 (1), 3-58. https://doi.org/10.1037/1089-2680.8.1.3

Konvalinka, Ivana et al.,

2011 "Synchronized Arousal between Performers and Related Spectators in a Fire-Walking Ritual", Proceedings of the National Academy of Sciences 108 (20), 8514-8519. https://doi.org/10.1073/pnas.1016955108

Krippner, Stanley \& Jeanne Achterberg

2000 "Anomalous Healing Experiences", in: Etzel Cardeña, Steven Jay Lynn \& Stanley Krippner, eds. Varieties of Anomalous Experience: Examining the Scientific Evidence, Washington, DC: American Psychological Association, 353-395. https://doi.org/10.1037/10371-011

Laland, Kevin N.

2017 Darwin's Unfinished Symphony: How Culture Made the Human Mind, Princeton: Princeton University Press. https://doi.org/10.1515/9781400884872

Leonard, William R. et al.

2003 "Metabolic Correlates of Hominid Brain Evolution", Comparative Biochemistry and Physiology Part A 136, 5-15. https://doi.org/10.1016/S1095-6433(03)00132-6

Liénard, Pierre \& Pascal Boyer

2006 "Whence Collective Rituals? A Cultural Selection Model of Ritualized Behavior", American Anthropologist 108 (4), 814-827. https://doi.org/10.1525/aa.2006.108.4.814 
Liénard, Pierre \& Jesper Sørensen

2013 "Tools for Thought: The Ritual Use of Ordinary Tools", in: Armin W. Geertz, ed., Origins of Religion, Cognition and Culture, Durham: Acumen Publishing Limited, 341-364.

Lombard, Marlize \& Miriam Noël Haidle

2012 "Thinking a Bow-and-Arrow Set: Cognitive Implications of Middle Stone Age Bow and StoneTipped Arrow Technology", Cambridge Archaeological Journal 22 (2), 237-264. https://doi.org/10.1017/S095977431200025X

Luhrmann, Tanya M.

2011 "Hallucinations and Sensory Overrides", Annual Review of Anthropology 40, 71-85. https://doi.org/10.1146/annurev-anthro-081309-145819

Macknik, Stephen L., Susana Martinez-Conde \& Sandra Blakeslee

2010 Sleights of Mind: What the Neuroscience of Magic Reveals about Our Everyday Deceptions, New York: Henry Holt and Company.

Malafouris, Lambros

2008 "Between Brains, Bodies and Things: Tectonoetic Awareness and the Extended Self", Philosophical Transactions of the Royal Society B. Biological Sciences 363, 1993-2002. https://doi.org/10.1098/rstb.2008.0014

Maryanski, Alexandra

1992 "The Last Ancestor: An Ecological-Network Model on the Origins of Human Sociality", Advances in Human Ecology 2, 1-32.

1993 "The Elementary Forms of the First Proto-Human Society: An Ecological/Social Network Approach", Advances in Human Evolution 2, 215-241.

1995 "African Ape Social Networks: A Blueprint for Reconstructing Early Hominid Social Structure", in: J. Steele \& S. Shennan, eds., Archaeology of Human Ancestry, London: Routledge, 67-90.

2013 "The Secret of the Hominin Mind: An Evolutionary Story", in: D. Franks \& J. H. Turner, eds., Handbook of Neurosociology, New York: Springer, 257-287. https://doi.org/10.1007/978-94-007-4473-8_18

2018 Émile Durkheim and the Birth of the Gods: Clans, Incest, Totems, Phratries, Hordes, Taboos, Exogamy, Sodalities, Menstrual Blood, Apes, Churingas, Cairins, and Other Mysterious Things, London: Routledge, under udgivelse.

Mitkidis, Panagiotis et al.

2013 “Collective-Goal Ascription Increases Cooperation in Humans”, PLOS One 8 (5), 1-7. https://doi.org/10.1371/journal.pone.0064776

2014 “Does Goal-Demotion Enhance Cooperation?" Journal of Cognition and Culture 14, 263-272. https://doi.org/10.1163/15685373-12342124

Nickels, Martin K.

2006 "New Taxonomy for Apes and Humans". ENSI. Evolution and the Nature of Science Institutes, webdokument (set den 7. september 2017) http://www.indiana.edu/ ensiweb/lessons/hominins.html.

Nielbo, Kristoffer L. \& Jesper Sørensen

2011 "Spontaneous Processing of Functional and Non-Functional Action Sequences", Religion, Brain $\mathcal{E}$ Behavior 1 (1), 18-30. https://doi.org/10.1080/2153599X.2010.550722

Nielbo, Kristoffer L., Uffe Schjoedt \& Jesper Sørensen

2013 "Hierarchical Organization of Segmentation in Non-Functional Action Sequences", Journal for the Cognitive Science of Religion 1 (1), 71-97.

Ochs, Elinor \& Lisa Capps

1996 "Narrating the Self", Annual Review of Anthropology 25, 19-43. https://doi.org/10.1146/annurev.anthro.25.1.19

Olivier, G. et al.

1978 "New Estimations of Stature and Cranial Capacity in Modern Man", Journal of Human Evolution 7, 513-518. https://doi.org/10.1016/S0047-2484(78)80020-7 
Plotkin, Henry

2002 The Imagined World Made Real: Towards a Natural Science of Culture, London: Allen Lane, The Penguin Press.

Renfrew, Colin, Chris Frith \& Lambros Malafouris, eds.

2008/2009 The Sapient Mind: Archaeology Meets Neuroscience, Philosophical Transactions of the Royal Society B: Biological Sciences, 2008; genoptrykt, Oxford: Oxford University Press, 2009.

Richerson, Peter J. \& Robert Boyd

2005 Not by Genes Alone: How Culture Transformed Human Evolution, Chicago: The University of Chicago Press.

Rowlands, Mark

2003 Externalism: Putting Mind and World Back Together Again, Montreal, Kingston, Ithaca: McGillQueen's University Press.

Russon, Anne E., Kim A. Bard \& Sue Taylor Parker, eds.

1996 Reaching into Thought: The Minds of the Great Apes, Cambridge: Cambridge University Press.

Sapolsky, Robert M.

2017 Behave: The Biology of Humans at Our Best and Worst, New York: Penguin Press.

Schjoedt, Uffe et al.

2008 "Rewarding Prayers", Neuroscience Letters 443, 165-168. https://doi.org/10.1016/j.neulet.2008.07.068

2009 "Highly Religious Participants Recruit Areas of Social Cognition in Personal Prayer", Social Cognitive and Affective Neuroscience 4, 199-207. https://doi.org/10.1093/scan/nsn050

2011 "The Power of Charisma - Perceived Charisma Inhibits the Frontal Executive Network of Believers in Intercessory Prayer", Social Cognitive and Affective Neuroscience 6, 119-127. https://doi.org/10.1093/scan/nsq023

2013a “Cognitive Resource Depletion in Religious Interactions", Religion, Brain E Behavior 3 (1), 39-55. https://doi.org/10.1080/2153599X.2012.736714

2013b "The Resource Model and the Principle of Predictive Coding: A Framework for Analyzing Proximate Effects of Ritual", Religion, Brain \& Behavior 3 (1), 79-86. https://doi.org/10.1080/2153599X.2012.745447

Siegel, Daniel J.

2001 "Toward an Interpersonal Neurobiology of the Developing Mind: Attachment Relationships, 'Mindsight,' and Neural Integration", Infant Mental Health Journal 22 (1-2), 67-94. https://doi.org/10.1002/1097-0355(200101/04)22:1<67::AID-IMHJ3>3.0.CO;2-G

Spanos, Nicholas P.

1996 Multiple Identities \& False Memories: A Sociocognitive Perspective, Washington: American Psychological Association. https://doi.org/10.1037/10216-000

Sperber, Dan

1996 Explaining Culture: A Naturalistic Approach, Oxford: Blackwell Publishers.

Sterelny, Kim

2003 Thought in a Hostile World: The Evolution of Human Cognition, Oxford: Blackwell Publishing.

2012 The Evolved Apprentice: How Evolution Made Humans Unique, Cambridge: The MIT Press. https://doi.org/10.7551/mitpress/9780262016797.001.0001

Stout et al.

2008 “Neural Correlates of Early Stone Age Toolmaking: Technology, Language and Cognition in Human Evolution", Philosophical Transactions of the Royal Society B. Biological Sciences 363, 19391949. https://doi.org/10.1098/rstb.2008.0001

Sørensen, Jesper

2001 "Magi og rituel effikacitet - en kognitiv tilgang", Religionsvidenskabeligt Tidsskrift 38, 59-71.

2004 "Religion, Evolution, and an Immunology of Cultural Systems", Evolution and Cognition 10 (1), 61-73.

2007a "Ideernes epidemiologi og kulturens immunologi: Et forsvar for et kulturhistorisk 
forklaringsniveau", Antropologi 53, 5-16.

2007b A Cognitive Theory of Magic, Lanham et al.: AltaMira Press.

2007c "Acts That Work: A Cognitive Approach to Ritual Agency", Method E Theory in the Study of Religion 19 (3-4), 281-300. https://doi.org/10.1163/157006807X240118

Targ et al.

2000 "Psi-Related Experiences", in: Etzel Cardeña, Steven Jay Lynn \& Stanley Krippner, eds., Varieties of Anomalous Experience: Examining the Scientific Evidence, Washington, DC: American Psychological Association, 219-252. https://doi.org/10.1037/10371-007

Tattersall, Ian

2012 Masters of the Planet: The Search for Our Human Origins, New York \& Houndmills: Palgrave Macmillan.

Taves, Ann

2009 Religious Experience Reconsidered: A Building-Block Approach to the Study of Religion and Other Special Things, Princeton \& Oxford: Princeton University Press.

Taylor, Kathleen

2004 Brainwashing: The Science of Thought Control, Oxford: Oxford University Press.

Tomasello, Michael

1999 The Cultural Origins of Human Cognition, Cambridge: Harvard University Press.

Turner, Jonathan $\mathrm{H}$.

2000 On the Origins of Human Emotions: A Sociological Inquiry into the Evolution of Human Affect, Stanford: Stanford University Press.

Turner, Jonathan H. \& Alexandra Maryanski

2008 On the Origin of Societies by Natural Selection, Boulder: Paradigm Publishers.

Turner, Jonathan H., Alexandra Maryanski, Anders Klostergaard Petersen \& Armin W. Geertz

2017 The Emergence and Evolution of Religion: By Means of Natural Selection, London: Routledge.

Turner, Jonathan H. \& Jan E. Stets

2005 The Sociology of Emotions, Cambridge: Cambridge University Press. https://doi.org/10.1017/CBO9780511819612

Vase, Lene \& Gitte Uldall Petersen

2011 "Placebo-effekter. Har patienters tanker og følelser indflydelse på, hvor godt en behandling virker?" in. Henrik Høgh-Olesen \& Thomas Dalsgaard, eds., 20 Psykologiske eksperimenter - der ændrede vores syn på mennesket, Hinnerup: Plurafutura publishing, 341-358.

Vilensky, J. A. et al.

1982 "The Limbic System and Human Evolution", Journal of Human Evolution 11, 447-460. https://doi.org/10.1016/S0047-2484(82)80099-7

Vyse, Stuart A.

1997 Believing in Magic: The Psychology of Superstition, Oxford: Oxford University Press.

Washburn, S. L.

1959 "Speculations on the Interrelations of Tools and Biological Evolution", in: J. M. Spuhler, ed., The Evolution of Man's Capacity for Culture, Detroit: Duke University Press, 21-31.

Whitehouse, Harvey

2000 Arguments and Icons: Divergent Modes of Religiosity, London: Oxford University Press.

Wrangham, Richard W.

2009 Catching Fire: How Cooking Made Us Human, New York: Basic Books.

Wulff, David M.

1991 Psychology of Religion: Classic and Contemporary Views, New York: John Wiley \& Sons.

2000 "Mystical Experience", in: Etzel Cardeña, Steven Jay Lynn \& Stanley Krippner, eds. Varieties of Anomalous Experience: Examining the Scientific Evidence, Washington, DC: American Psychological Association, 397-440. https://doi.org/10.1037/10371-012 
Xygalatas, Dimitris et al.

2011 "Quantifying Collective Effervescence: Heart-Rate Dynamics at a Fire-Walking Ritual", Communicative \& Integrative Biology 4 (6), 735-738. https://doi.org/10.4161/cib.17609

2013a "Autobiographical Memory in a Fire-Walking Ritual", Journal of Cognition and Culture 13 (1), 116. https://doi.org/10.1163/15685373-12342081

2013b “Extreme Rituals Promote Prosociality”, Psychological Science 24 (8), 1602-1605. https://doi.org/10.1177/0956797612472910

Zindler, R. E.

1978 "On the Increase of Cranial Capacity in Mankind's Lineage: Augments and Elaborations", Journal of Human Evolution 7, 295-305. https://doi.org/10.1016/S0047-2484(78)80071-2

Armin W. Geertz, professor, dr.phil. Afdeling for Religionsvidenskab, Aarhus Institute of Advanced Studies, Aarhus Universitet awg@cas.au.dk 